\title{
Libidinal Life: Bram Stoker, Homosocial Desire and the Stokerian Biographical Project
}

\begin{abstract}
This paper offers an examination of the Stokerian biographical project and shows how many biographies of Bram Stoker are invested in uncovering the elusive relationship between this little-known author and the actor Henry Irving. An exploration of Stokerian biographies reveals how Stoker has been constructed as a man who experienced same-sex desire, as revealed through his own "autobiographical" texts, such as Personal Reminiscences of Henry Irving and Dracula. Eve Kosofsky Sedgwick's concept of "homosocial desire" provides a useful theoretical framework within which to explore a sample selection of Stokerian biographies, including those of Daniel Farson, Phyllis A. Roth, Barbara Belford and Paul Murray. This paper maintains that the theories surrounding Stoker's libidinal life are generally well-grounded, yet to this day several questions remain unanswered. For many biographers, the life of the author of Dracula continues to be shrouded in mystery.
\end{abstract}

\section{Key words}

Bram Stoker; biography; Personal Reminiscences of Henry Irving; Dracula; Eve Kosofsky Sedgwick; homosocial desire

We were struck with the fact, that in all the mass of material of which the record is composed, there is hardly one authentic document; nothing but a mass of typewriting [...] (Dracula)

In late-nineteenth-century England, sexual attitudes which deviated from the norm were both demonized and feared. This is reflected in the works of Victorian author Bram Stoker, for whom adherence to tradition and fixed gender roles were of utmost importance. Yet a biographical portraiture of the man behind Dracula 
reveals seemingly conflicting findings. Many claim that the fiercely conservative author exposes his inner maverick upon closer investigation. One of Stoker's most obscure works, Personal Reminiscences of Henry Irving, for instance, sheds light on the author's intense preoccupation with men of power, in particular with the famed actor Henry Irving. Further, Irving is said to have inspired much of the text of Dracula, Stoker's most famous novel. Interestingly, Stoker's obsessive fixation with Irving has become a popular topic for Stokerian life-writers in recent years. This paper offers an analysis of the biographical focus upon the sexuality of Bram Stoker, as revealed through a sample selection of contemporary Stokerian biographies. Biographical works dealing with the life of Bram Stoker largely rely upon the author's own literary output for autobiographical "clues" into their subject's elusive sex life. With this in mind, Eve Kosofsky Sedgwick's concept of "homosocial desire" may be used to elucidate the ways in which Stoker is depicted in biography.

\section{Bram Stoker and "Homosocial Desire"}

With the recent surge of Stokerian biographies, the author of Dracula, like the immortal count, has come to represent a figure of illicit sexuality. It is interesting to undertake an exploration of how Stoker has been perceived in what I refer to as the "Stokerian biographical project," where the texts of Personal Reminiscences of Henry Irving and Dracula, among others, have come to be regarded as expository works, revealing Stoker's unstable sex life. Indeed, biographers point out that the texts in question contains important autobiographical revelations about the author's sexuality, displaying how Stoker's life and works are inescapably linked to the world of forbidden fantasies. By examining the ways in which sexuality and gender relations are presented within the Stokerian biographical project, one may uncover how the libidinal life of this little-known author may reveal more about our own desires as readers than those of Bram Stoker.

Without a doubt, life-writers have come to eroticize Stoker in biography and to engage in queer readings of Personal Reminiscences and Dracula. Eve Kosofsky Sedgwick's insights into the "cult(ure)" of nineteenth-century bachelors are particularly relevant to the study of this late-Victorian author. Using Sedgwick's notion of "homosocial desire" as a lens through which to analyze Stokerian biographies, I propose that the man behind Count Dracula has ultimately been merged with Irving, and that an understanding of one is incomplete without the other. Indeed, by seeking out revealing passages from Stoker's Personal Reminiscences of Henry Irving as well as autobiographical elements derived from the text of Dracula, many biographers tend to represent Bram Stoker as a closeted person who experienced subversive desire for none other than the famed actor Henry Irving.

In Sedgwick's Between Men: English Literature and Homosocial Desire, the author reclaims the term "homosocial" and links it to the concept of desire. Through her analysis of English culture, most particularly her engagement with 
the mid-eighteenth to mid-nineteenth-century novel, Sedgwick notes the somewhat compelling, recurrent trope of same-sex affection between men. By relating the idea of the "social" with the notion of "desire" (which she notably distinguishes from "love"), the author effectively sexualizes the idea of the "homosocial," all the while stressing that it is discernable from the phenomenon of homosexuality. Sedgwick sees the idea of "homosocial desire" as the "social bonds between persons of the same sex" (1985: xiii), examples of which include " "male bonding,' which may in our society be characterized by intense homophobia, fear and hatred of homosexuality" (1). Moreover, the author underlines that for a "homosocial" bond between males to occur, an isolated environment or delineated space is required, where there is often a conscious and deliberate exclusion of women. Sedgwick further underlines that the idea of "homosocial desire" emerges from the cultural traditions of the eighteenth and nineteenth centuries (as aforementioned), where different forms of male bonding began to be viewed with much greater suspicion than they had in earlier periods. Out of the fear arising from homophobia - a fear generally directed towards men, but occasionally women as well ${ }^{1}$ - was born the need to qualify proper and indecent forms of male attachment. For Sedgwick, the realms of the homosocial and homosexual differ, yet, at the same time, display certain affinities. The author explains how she envisions the twin concepts of homosociality and homosexuality as being along the same spectrum: "To draw the 'homosocial' back into the orbit of 'desire' [...] is to hypothesize the potential unbrokenness of a continuum between homosocial and homosexual - a continuum whose visibility, for men, in our society, is radically disrupted" (1985: 1-2). In short, Sedgwick's notion of "homosocial desire" may be categorized as being on the same plane of existence as the homosexual, thereby displaying that these two forms of male relations share notable similarities.

In Stoker's works, and Dracula in particular, the realm of the homosocial may likewise be understood as bordering closely along that of the homosexual. Certain bonds between men might be said to be "separated only by an invisible, carefully blurred, always-already-crossed line from being 'interested in men"' (Sedgwick 1985: 89). Biographers and critics alike have pointed to the timely publication of Stoker's vampire novel two years after the advent of the 1895 trial of Oscar Wilde, ${ }^{2}$ an incident that significantly marked "the beginnings of dissemination across classes of language about male homosexuality" (Sedgwick 1985: 179). Sedgwick reveals that, during this period in gay history, intercourse between men was not directly referred to, but rather was known as an "unspeakable" act, ${ }^{3}$ and this trope of the unspeakable constantly manifests itself throughout Victorian literature (1985: 94). Sedgwick, thus, provides a useful way of exploring relations between men in the Victorian era, as Stephen Arata concurs:

[T] he continuum linking the homoerotic and the homosocial is central to modern Western cultures, yet it is also invariably occluded. Making the links visible can help us better to see among other things, the specific historical circumstances to which different forms of male bonding respond. (1996: 79) 
Arata underscores that Sedgwick's notions about masculinity help to navigate through a social study of relations "between men," and Stoker certainly provides an ideal homosocial subject from this perspective. Bearing this in mind, an analysis of Stoker's homosocial portrayal in biography, which focuses largely on his relationship with Irving, may be undertaken.

\section{The Stokerian Biographical Project}

The Stokerian biographical project represents an important yet often overlooked facet of the phenomenon that is Dracula. The first comprehensive biography of Stoker appeared in 1962 with Harry Ludlam's A Biography of Dracula: The Life Story of Bram Stoker. In the 1970s, Stoker's work was excavated by Freudians who found that a stake was more than just a stake. The novel began to receive widespread critical attention with the publication of Leonard Wolf's The Annotated Dracula (1975). Although Wolf - arguably the first Dracula scholar - has acknowledged the possibility that vampirism in the text represents a coded manifestation of repressed sexual desires, Stoker himself fervently denied this interpretation. ${ }^{4}$ Although Stoker remained steadfast in his view that there was nothing sexual in his famous Gothic tale, biographers contend that the stalking, sucking and staking in Dracula must have registered on some suggestive plane in the mind of its author. Indeed, Barbara Belford notes that Stoker was conscious of the subtext of Dracula: "Stoker was an intelligent and insightful man [...] He was many things, but naïve was not one of them; he was fully aware of the subtexts in his horror tale" (1996: xii-iii). Clearly, many biographers and critics find themselves at the opposite end of Stoker's interpretive spectrum.

Dracula scholars now abound, and several biographies have come to the fore, each promising a new and more exhaustive study of Stoker than the last. Despite the different approaches that these life-writers take, all focus largely upon Stoker's unique relationship with Henry Irving, the most celebrated actor of the nineteenth century, whom Stoker served as acting manager and unofficially as personal assistant and secretary (Dorn 1997). ${ }^{5}$ Biographers claim that Irving was the main inspiration for Count Dracula, and that any understanding of this masterpiece is incomplete without recognizing the immeasurable extent of the actor's impact upon Stoker's literary career. Many have described the friendship as one where Irving - like the notorious Count - depleted Stoker both physically and emotionally, from the moment they met until Irving's last breath.

Stokerians generally agree that the author's slavish devotion began on his first meeting with Irving. ${ }^{6}$ They further recount other memorable episodes in the Stoker-Irving saga, such as when Irving hired aids to unofficially take over Stoker's position, thus "betraying" his loyal friend. Even after Irving's death, Stoker persisted in his devotion to Irving, and in 1906 wrote the idolatrous two-volume, 760-page biography entitled Personal Reminiscences of Henry Irving, a work that ironically reveals much about the author himself. By exploring the treasure 
trove of hidden meanings that lie within Personal Reminiscences and Dracula, many biographers have advanced different theories surrounding Stoker's elusive sexuality and possible homosexual attraction to Irving. Although the author of Dracula still remains in the realm of the shadows, these commendable biographical works dare to speculate on the sexuality of their subject in light of the homosocial culture of late-Victorian London. A sample study of some of the most prominent Stokerian biographies include: Daniel Farson's The Man Who Wrote Dracula: A Biography of Bram Stoker (1975), Phyllis A. Roth's Bram Stoker (1982), Barbara Belford's Bram Stoker: A Biography of the Author of Dracula (1996), and Paul Murray's From the Shadow of Dracula: A Life of Bram Stoker (2004). ${ }^{7}$

Contemporary Stokerian biographers have acknowledged and continuously return to the possibility that Stoker was a closeted homosexual who was in love with Irving. Through the years, life-writers become progressively audacious in their discussions of Stoker's same-sex desire; less recent biographies naturally approach this topic with caution. Farson, for instance, focuses more or less on Stoker's heterosexual behavior, since sexual ambiguity was not a topic that biographers felt as comfortable discussing in the 1970s as they do today. Nevertheless, he often insinuates that Stoker might have been interested in men. For instance, he begins his chapter entitled "The Sexual Impulse" with the telling statement "It was a great friendship," referring to Stoker and Irving (Farson 1975: 203). Roth further engages with this topic in a more direct manner, noting that "Stoker's friendship with Irving was the most important love relationship of his adult life" (1982: 136). Belford is even more straightforward about the issue, and remarks that "The Beefsteak Room," which Stoker frequented, was a " "homosocial' world of masculine privilege in which women were used as pawns" and where there was evidence of "the shadow of homosexuality" (1996: 127). ${ }^{8}$ Murray is equally forthright, declaring that "[h]omosexuality on Stoker's part could have been [...] [a] reason for discontinuation of heterosexual relations with Florence" (2004: 80). To be sure, there is a progressive desire on the part of biographers to address the topic of Stoker's ambiguous sexuality, and the more current the biographer, the more likely they are to advance the possibility that Stoker was a closeted person. Due to this "evidence," biographers would no doubt agree with the idea that, as a biographical subject, Stoker might be examined within a homosocial framework.

In biography, Stoker is arguably depicted as one who, among other things, experienced "homosocial desire" for his friend and employer Henry Irving. Because of the fact that his true feelings were never fully expressed and have remained shrouded in mystery, Stoker's obscure sex life has been a continuous source of speculation for biographers. One explanation as to why the author's most intimate thoughts and desires generate such interest is that he belongs to an exclusive class of educated bourgeois males who distinguished themselves in various ways during the late-Victorian period. As Sedgwick observes, "Biographies of English gentlemen of the nineteenth and early twentieth century are full of oddities, 
surprises, and apparent false starts; they seem to have no pre-determined sexual trajectory" (1985: 173). ${ }^{9}$ To be sure, Stoker's elusive "sexual trajectory" has generated many hypotheses indeed. Moreover, Stoker was acquainted with many of the well-known figures of the fin de siècle literary scene, including, as aforementioned, Oscar Wilde. ${ }^{10}$ Stoker had a particularly interesting affiliation with Wilde, as he won the heart and hand of Wilde's former sweetheart, Florence Balcombe (Belford 1996: 85). ${ }^{11}$ Despite his compliance with Victorian heterosexual norms through marriage, Stoker's sexual identity remains elusive.

\section{Bram Stoker's "Primal Scenes": Personal Reminiscences and Dracula}

It is precisely this aura of sexual unsteadiness that Stokerian biographers seek to expose, by discussing episodes throughout their subject's life that may be referred to as "primal scenes."12 For instance, it may be argued that biographers present the seemingly insignificant recital of Thomas Hood's ballad The Dream of Eugene Aram, The Murderer ${ }^{13}$ as indicative of a life-altering "primal scene" for Stoker, since it marks the date of his first official encounter with Irving. Stokerian biographers look to Personal Reminiscences, where Stoker reveals, in his own words, the impact Irving had upon him on the rainy December night in 1876 when they first met. Life-writers focus on Irving's recital, found in Book I of Personal Reminiscences, which he delivered with great emotion, calling it a "present" for Stoker, his newfound friend. Farson calls the groundbreaking event "The Fateful Meeting" (1975: 23), and goes into detail about what happened on that particular evening. Roth also mentions this crucial episode in the introduction and conclusion of her biography. Belford further highlights this watershed moment in her chapter entitled "Henry Irving" (1996: 70). Finally, for Murray, too, Stoker's reaction to the poem is a vital turning point in the author's life that he deems worthy of mention (2004: 71).

Stoker's significant reaction to the poetry recital helps to piece together the magnitude of the impact it had upon the author's life. In his own words, the author recalls that "[s]o great was the magnetism of his genius, so profound was the sense of his dominancy that I sat spellbound [...] [and] I burst out into something like a violent fit of hysterics" (Stoker 1906: I, 29-31). Stoker's admission that he experienced "a violent fit of hysterics" as a reaction to another man's poetry recital has naturally generated great interest and much speculation among the author's life-writers. To add fuel to the fire, Stoker seemingly felt the need to defend his erratic behavior, as he underscores later in Book I of Personal Reminiscences: "I was no hysterical subject. I was no green youth; no weak individual, yielding to a superior emotional force. I was as men go a strong man, strong in many ways" (Stoker 1906: I, 31). Stoker's vehement denial that he was "no hysterical subject" seems to have effectively worked against him, and not only built a stronger case for the theory of his homoerotic desire for Irving, but also and perhaps more importantly gestures towards the idea of female hysteria in Victorian England. ${ }^{14}$ 
In The Female Malady: Women, Madness, and English Culture, 1830-1980, Elaine Showalter indicates that hysteria was largely considered a female illness ${ }^{15}$ in Stoker's day, making it a rather dangerous avowal for a Victorian gentleman. The question that remains, of course, is whether Stoker was fully conscious of what he might be implying. Murray believes that, when his biographical subject wrote Personal Reminiscences, he was not ignorant of the implications of his statement: "Jean-Martin Charcot, of whom Stoker was well aware by the time he wrote Personal Reminiscences, saw hysteria as a disorder suffered by women or very impressionable men who were 'well-developed, not enervated by an indolent or too studious mode of life"' (2004: 73). Clearly, Murray and others contend that the author - a worldly fin de siècle fellow - should have known better than to publically confess to suffering from a feminine illness.

Stoker further reveals that the evening of the poetry recital marked the beginning of a deeply spiritual bond between Irving and himself, one that seemingly elevated him to a higher plane of existence. Indeed, he reveals once again in Personal Reminiscences that "soul had looked into soul! From that hour began a friendship as profound, as close, as lasting as can be between two men" (Stoker 1906: I, 33). Stoker then goes on to pontificate that at "the sight of his [Irving's] picture before me, with those loving words, the record of a time of deep emotion and full understanding of us both, each for the other, unmans me once again as I write" (1906: I, 33, emphasis mine). Stoker's telling word-choice here displays that his bout of hysteria was not an isolated incident; but rather indicates how he repeatedly describes himself in feminine terms. Like the aforementioned admission of hysteria, this passage has likewise been interpreted by many biographers as a declaration of same-sex desire. These bizarre disclosures on Stoker's part have been interpreted by many as a form of confirmation that he harbored secret desires for his friend, and certainly serves as valuable primary material for Stoker's life-writers. Moreover, by professing that he "was no green youth; no weak individual," Stoker effectively implies that feeble women, rather than stalwart males, were typically subject to hysteria. Despite this, the author still admits to having felt the onset of hysterics in Personal Reminiscences, thereby indicating to his readership the extent of Irving's colossal impact upon him. What is made clear is that Personal Reminiscences contains many autobiographical statements on some of Stoker's most personal experiences. Instead of suffering from male hysteria, ${ }^{16}$ biographers posit that it is much more plausible that Stoker's emotional turbulence reflected deep-seeded feelings of homosocial/homoerotic desire. Stoker purportedly maintained a heteronormative façade in his day-to-day existence, yet contemporary examinations of his life have recently unveiled the author's sexually ambiguous underbelly.

Moreover, Stoker's momentary mental breakdown, as recorded in Personal Reminiscences, demonstrates the Victorian taboo against a male's outward expression of passionate sentiments, which Sedgwick might accordingly describe as the "oppressive of the so-called feminine in men" (Sedgwick 1985: 20). The incident of Irving's poetry recital and the consequent impression it left upon the 
author arguably serves to centralize the biographical narratives of many Stokerian life-writers. Although Stoker apparently felt the need to belittle the significance of his excessive display of ardor as a temporary bout of weakness, his attempt at doing so had the unintentional effect of further highlighting its import for biographers. As Farson points out, Stoker "stressed his physical strength, not in his vindication but in praise of Irving's 'splendid power' which had moved him so greatly" (1975: 30). Roth further notes that after this confession, Stoker "feels the need to qualify his reaction with one of the longest autobiographical statements in Personal Reminiscences, a statement in which he describes [...] his great psychological and physical strength as an adult" (1982: 132-33). In other words, Stoker confirms that he is both masculine and mature. However, Belford sees Stoker's rant as over-compensatory, and pictures him instead as remarkably juvenile: "[H]e had an impressionable disposition [...] Irving had on this evening intruded on Stoker's immaturity" (1996: 74). In essence, the pivotal "primal scene" of Stoker's biographical life arguably centers around Irving's poetry recital, and further illustrates how the author's peculiar confession is interpreted as symbolic of his quarter-century relationship with Irving. The episode further informs the shape that Stoker's life would henceforth take, and the Stokerian biographies under investigation stress that the obsessive admiration he felt for Irving on the night of the poetry recital would forever enslave him. Indeed, this key incident in Personal Reminiscences provides major support in constructing the man who wrote Dracula as a sexually elusive figure whom biographers tirelessly examine as the secret admirer of Henry Irving.

This life-altering "primal scene" of the poetry recital aside, other key moments in the Stoker-Irving saga further reinforce the biographical construction of the author as sexually elusive. Later in Personal Reminiscences, for instance, Stoker goes so far as to use marital imagery to convey the depth of his bond with Irving:

Irving and I were so much together that after a few years we could almost read a thought of the other; we could certainly read a glance or an expression. I have sometimes seen the same capacity in a husband and wife who have lived together for long and who are good friends, accustomed to work together and to understand each other.

(1906: I, 364, emphasis mine)

Here, Stoker envisions Irving as a spouse, an assertion that has not been lost on the author's biographers. In addition to what may be considered a declaration of love by many critics, the passage further reveals that Irving clearly holds power over Stoker. Biographers have likewise examined other sources besides Personal Reminiscences, such as notebooks and letters by the author, which point to evidence of same-sex love between men. Murray notes that long before his relationship with Irving began, Stoker described himself in one of his notebooks in 1871 as "a strong man with a woman's heart and the wishes of a lonely child" (2004: 65). Such statements and countless others continue to mystify the author's life-writers. 
In analyzing Stoker's assertions with regards to Irving, biographers tend to depict the relationship between the two men as beset by inequality. Although Stoker desired more than anything to form a partnership based on mutual respect, he is, instead, portrayed in biography as a man who was subservient to the overbearing Irving. As Murray explains: "Stoker's relationship with Irving had undergone a sea of change [...] from close friendship to that of a subordinate to a superior" (2004: 101). Indeed, the nature of the union was such that Stoker called Irving "Chief" and "Guv'nor" (Belford 1996: 100). The AngloIrish writer is depicted as somewhat of an inferior type, a man whose career was defined by a life of obedience to the imperious actor. Belford confirms this characterization, stating that Irving was to adopt "an evil parental role [in relation to Stoker], the most felicitous ever written for him" (1996: 5). Belford further holds that Irving not only controlled Stoker in a work environment, but also compromised the relationships with his kith and kin. Indeed, she contends that Irving "stole away Stoker's family life. But Stoker was a willing victim; he much preferred Irving's company to an evening in front of the fire with Florence cradling their newborn" (Belford 1996: 121) ${ }^{17}$ The author of Dracula is thus arguably presented by biographers as a man who was so dedicated to his employer that he neglected his family.

To be sure, the Irving/Stoker relationship has been constructed in biography as what Sedgwick might refer to as a "hypercharged and hyperarticulated paternalis[tic] [...] bond between male servant and male employer" (1985: 162). The idea of Stoker as a "male servant" may certainly apply to the man behind Dracula, such was the extent of his dedication to the actor. Stoker was not, however, the only drudge willing to worship Irving, a fact that is brought to the fore once again in the Stokerian biographical project. Hopefuls for Stoker's position as acting manager and personal assistant to Irving abounded, and the likes of Louis F. Austin were "insinuating [themselves] into Irving's inner circle" (Belford 1996: 173). Stokerian biographers relate how their subject became jealous of the attention Irving provided to his other comrades such as Austin, and how the author reacted by "ignor[ing] [Austin] and thereby infuriated him" (Belford 1996: 174). Roth elaborates upon this point, highlighting that "Stoker's relationship with Irving was apparently not without its tensions and rivalries" (1982: 136). Farson adds that "Irving's preference for Austin as his literary adviser must have shaken any belief Bram had that he was indispensable" (1975: 86). Although Stoker's loyalty for Irving never swayed, Belford notes that his "infatuation with men of power continued, doubtless aided by his growing insecurities over Irving's affection" (1996: 189). Murray interprets the competition for Irving's attention differently, claiming that "Irving indulged his sardonic sense of humor by fanning a sense of rivalry between Austin and Stoker" (2004: 104). Biographers thus highlight the fact that Stoker often vied for Irving's attention, and that his hard work frequently went unnoticed by the actor.

After Irving's passing in 1905, Stoker's ostensible obsession with the actor did not fade, but instead grew stronger, according to his biographers. Even though 
Irving's will contained "not even a small token of appreciation for Stoker" (Dorn 1997), he nevertheless produced his idolatrous biography of Irving in 1906, Personal Reminiscences. The work has, in turn, become a major source upon which many writers rely for their own biographies of Stoker, since he often graces his readers with autobiographical information throughout this two-volume opus. Indeed, when the biography first appeared, one critic remarked that "in Mr. Bram Stoker's 'Personal Reminiscences of Henry Irving' [...] there is a little too much of Mr. Bram Stoker" (qtd. in Senf 1993: 137). Although personal information about Stoker was seen as superfluous in the early years of the twentieth century, it is viewed as providential for current Stokerian biographers. Indeed, first-hand information from the subject or recollections in their own words are considered extremely valuable for the modern biographical project, if not the most important source of information. ${ }^{18}$

Stoker's brief stint as a biographer has naturally been of great interest to contemporary Stokerian biographers themselves. Belford holds that Personal Reminiscences represents the author's rather subjective account of Irving's life story, a recollection that reflects unabashed apotheosis. She calls the work "two volumes of unobjective idolatry with occasional insights into himself, but he could not (or would not) bring himself to look critically at the Irving legend, such was his loyalty" (1996: 307). Belford further highlights the fact that Stoker goes so far as to quote Elizabeth Barrett Browning to convey what he calls his feelings of "heartbreaking sincerity" with regards to his memories of Irving (308). Naturally, the fact that Stoker borrows from Browning - best remembered for her Sonnets from the Portuguese - has yet again been viewed as symbolic. Reflecting upon their relationship after Irving's death, Stoker remembers the actor with reverence:

Looking back, I cannot honestly find any moment in my life when I failed him, or when I put myself forward in any way [...] In my own speaking to the dead man I can find an analogue in the words of heartbreaking sincerity [of Mrs. Browning]:

Stand up on the jasper sea

And be witness I have given

All the gifts required of me!

(Stoker 1906: I, 34)

Stoker's posthumous adulation of Irving, including the reference to the poem "Bertha in the Lane," not only recalls the equally emotional poetry recital of The Dream of Eugene Aram, but has also been regarded as yet another piece of the puzzle in the on-going construction of Stoker's elusive sex life. Stokerians clearly stress their subject's deep admiration for Irving, and either imply or strongly suggest that Stoker simply adored the actor. Farson, for instance, points out that Personal Reminiscences is a testament to their union: " Love' is not too strong a word for the relationship that developed," and which only terminated with death (1975: 
27, author's emphasis). Roth adds that Personal Reminiscences "sustains the tone of deeply affectionate respect and unqualified admiration which marked Stoker's feelings for the man he served so devotedly" (1982: 18-19). This slave-like dedication was to be Stoker's destiny in Murray's point of view: "It was Stoker's fate to be associated with Henry Irving for the rest of his life" (2004: 237). Indeed, in his 1912 obituary, Stoker's greatest literary achievement was ironically said to be Personal Reminiscences, rather than his now legendary vampire tale.

Despite his numerous declarations with regards to Irving, it must be remembered that Stoker never provided unequivocal proof of his same-sex desire, the way Oscar Wilde did, for instance. Nevertheless, biographers suggest that he might have experienced passionate feelings for the actor that he was too afraid to express. Naturally, Stoker was well aware of Victorian "scientific models [...] [which] identified (or constructed as deviant) 'aberrant' sexual practices [...] such as homosexuality" (Smith 2004: 99); thus, it has been theorized that this persuaded the author to keep his deepest desires in check. The construction of Stoker as a man who supposedly experienced secret same-sex desires relates to the Sedgwickian idea of "closetedness," which is said to represent "the relations of the known and the unknown, the explicit and the inexplicit around [the] homo/ heterosexual definition" (1990: 3). Certainly, the unknown aspects of the StokerIrving relationship add to the mystique and intrigue surrounding this elusive author. This, in turn, contributes to Stoker's creation as a fascinating biographical subject, since the shroud of sexual mystique surrounding him ultimately helps ensure that his biographies become appealing to mass audiences. It is evident that sexuality plays a major part in the biographical construction of the subject, and in Stoker's case in particular. Marjorie Gaber suggests that an interesting libidinal history "is one presumptive reason why the book is being purchased, reviewed, read, or in fact written" (1996: 22). Certainly, the Stokerian biographical project has gone through great pains to unveil the mysteries that surround the sex life of the man who wrote Dracula, yet there are still many unknowns. In short, Stoker's elusive sexual trajectory can be examined through his memoir Personal Reminiscences, and his biographers explore this revealing work when recounting the author's life-story in relation to Irving. Stoker's fiction, and Dracula in particular, can likewise be read as autobiographical, and Stokerian life-writers have also engaged in numerous readings of this vampire text in order to better understand the nature of the relationship between Stoker and Irving.

Without a doubt, biographers unanimously agree that Dracula is a largely autobiographical work, and that key individuals in the author's life are represented as significant characters within the text. ${ }^{19}$ Some hold that the novel can be understood as a window into the obscure sex life of its author, similarly to Personal Reminiscences. Belford has gone so far as to claim that Stoker "dumped the signposts of his life into a supernatural cauldron and called it Dracula" (1996: 256). Moreover, Jeffrey Jerome Cohen sees Irving as Stoker's muse, noting that "we might explore the foreign count's transgressive but compelling sexuality, as subtly alluring to Jonathan Harker as Henry Irving, Stoker's mentor, was to Stoker" 
(1996: 5). To be sure, Irving's importance in Stoker's life cannot be overlooked, and his mystifying liaison with the author may be explored within the context of Stoker's well-known vampire tale.

Dracula is certainly Stoker's most famous work, and elements of unfixed sexuality and unstable gender roles can be found throughout the text. Here, Stokerian biographers point out that not only have Stoker's characters become sexualized but, as in the case with Personal Reminiscences, the author himself has also incited speculation with regards to his seemingly unfixed sexuality. Moreover, Sedgwick's concept of homosocial desire may certainly be applied to a reading of the novel, since she sees the Gothic novel as particularly effective in relaying this idea. Indeed, she highlights that "[t]he paranoid Gothic was the novelistic tradition in which the routing through women of male homosocial desire had the most perfunctory presence" (1985: 118). Certainly, Stoker's Dracula may arguably fall within this category, as an example of a late-Victorian "paranoid Gothic" text.

Examined from the point of view of Stoker's fiction, Irving is considered by many Stokerians and Dracula scholars alike to be the central model for the father of all vampires (Murray 2004: 177). Bearing in mind Irving's paramount importance upon Stoker's writings, many biographers agree that reading Dracula potentially yields autobiographical findings about Stoker, more particularly about how he regarded Irving. In chapter two of Dracula, for instance, Jonathan Harker tells of his first meeting with the Count. ${ }^{20}$ The latter's physical description is recounted with meticulous attention to detail, as he is portrayed as a strikingly "tall old man, clean shaven save for a long white moustache, and clad in black from head to foot" (Stoker 2008: 42). In addition, he has a distinctive face, with "a strong a very strong - aquiline, with high bridge of the thin nose" (Stoker 2008: 44). As Belford observes, his countenance in some ways resembles Irving's noticeably aquiline features (1996: 239) ${ }^{21}$ Similarly, Irving is said to have been a rather eccentric figure that "defied description" and who possessed "an incomparable power for eeriness" (Belford 1996: 71). Roth also notes that the similarities between Irving and Dracula were so great that Stoker might have written the work "expressly to be performed by Henry Irving" (1982: 136). However, Murray is convinced that the similarities between the two are more psychological in nature, noting that "the case for seeing Irving as Dracula [...] is based largely on [...] an alleged feeling on Stoker's part [...] that he was exploited by the actor" (2004: 177). Belford reiterates this point, adding that Dracula became "a sinister caricature of Irving as a mesmerist and a depleter, an artist draining those about him to feed his ego" (1996: 270). As such, biographers and critics largely agree that Stoker's most famous work contains important autobiographical information, with allusions to Irving as a physically and mentally overbearing figure, much like the Count himself.

A brief autobiographical examination of Stoker's novel, more specifically an exploration of the apparent tension represented between Jonathan and Dracula, may reveal some of Stoker's deepest feelings towards Henry Irving. It has been suggested that the character of Jonathan Harker is meant to represents Stoker "Stoker's alter ego," according to Belford - and that Irving stands for the evil 
Count Dracula, as aforementioned. In Stoker's work, the Count threatens to destroy Jonathan's fragile mental state, just as he has Renfield's before him. When Jonathan enters Castle Dracula, he soon loses his grip on power, and effectively becomes the vampire's prisoner. For biographers, the most significant "primal scene" from an autobiographical perspective consists in the moment where Dracula intercepts the weird sisters and saves Jonathan from their deadly embrace. ${ }^{22}$ Belford views the episode as "Stoker's most revealing scene from a biographical point of view" (1996: 7). Here, demonic women prepare to attack the helpless Englishman, who has succumbed to their lustful appetites. Just before they proceed with their fatal kiss, Dracula violently interrupts them, claiming Jonathan as his own:

I [Jonathan] was conscious of the presence of the Count, and of his being as if lapped in a storm of fury [...] His eyes were positively blazing. The red light in them was lurid, as if the flames of hell fire blazed behind them. His face was deathly pale, and the lines of it were hard like drawn wires. The thick eyebrows that met over the nose now seemed like a heaving bar of white-hot metal. With a fierce sweep of his arm, he hurled the woman from him, and then motioned to the others, as though he were beating them back. It was the same imperious gesture that I had seen used to the wolves. In a voice which, though low and almost in a whisper seemed to cut through the air and then ring in the room he said, "How dare you touch him, any of you? How dare you cast eyes on him when I had forbidden it? Back, I tell you all! This man belongs to me! Beware how you meddle with him, or you'll have to deal with me."

(Stoker 2008: 81-82, emphasis mine)

Belford reads this scene - especially when Dracula declares: "This man belongs to me!" - as the Victorian male fear that "Dracula will seduce, penetrate (with his phallic shaped canine teeth), and drain another male [...] Nowhere in the novel is Irving's mesmeric control over Stoker more manifest" (1996: 7). Without a doubt, such examples display how biographers hone in on specific episodes in Stoker's best-known work to uncover his possible subversive desire for Irving. Viewed from a Sedgwickian perspective, it is clear that one of the world's most famous horror tales could be said to gesture towards the concept of male homosocial desire, a claim that several biographers have readily made. Sedgwick's understanding of "homosocial desire" is once again an appropriate lens through which to examine at the life of the author of Dracula, considering the tumultuous relationship he shared with the famed actor Henry Irving. The notion of "homosocial desire," thus, not only addresses the possibility of male romance, but as James Eli Adams indicates, is, in a more general sense, a concept that is "central to social power [...] traditionally almost every social structure [...] locates power in some form of bond between men" (1999: 134). In short, the notion of homosocial desire and the possibility of same-sex love can be applied to an au- 
tobiographical reading of Personal Reminiscences as well as Dracula. Though biographers admittedly present the mysterious liaison between Stoker and Irving from "various angles of vision, so that their subject, instead of being flattened out, attains a three-dimensional quality" (Edel 1959: 152), they nevertheless focus extensively on the idea of unfixed sexuality in the life of the author of Dracula.

This paper has examined the biographical construction of the historical Bram Stoker as a sexually elusive figure. Stokerian biographers often rely upon the author's own works, such as his little-known biography of Henry Irving, Personal Reminiscences of Henry Irving as well as his gothic novel, Dracula, in their attempts to reconstruct the life of this little-known author. Of late, the Stokerian biographical project has advanced various theories concerning Stoker's sexuality, displaying the extent to which the author's fiction and life-history have been absorbed together into Dracula's "dense narrative whirlpool" (Davison 1997: 148). By exploring the figure of Bram Stoker through his "autobiographical" texts, many life-writers have deduced that the author harbored illicit desires that he may - or may not - have acted upon. Biographers generally agree that the life of Bram Stoker is rendered comprehensible through his relationship with Henry Irving, a figure that remains crucial to the full understanding and appreciation of Dracula. Indeed, Daniel Farson, Phyllis A. Roth, Barbara Belford and Paul Murray all reveal that Irving had a central role in shaping Stoker's life and literary career, but that he was also forever cast as Irving's subordinate. Viewed in light of the homosocial world of Victorian England, Stoker has led biographers to pontificate about his seemingly ambiguous sexuality, a topic that dated Stokerians have hinted at and which more recent biographers have openly acknowledged. In light of this, Sedgwick's notion of "homosocial desire" provides a useful theoretical framework to help situate a biographical analysis of the historical Stoker. Since much scholarly debate surrounding Stoker's sexuality exists, the case has yet to be closed. By unearthing the man behind the vampire through the study of his very own works, Stokerians have effectively brought their subject back to life for readers today. Yet in a post-Freudian world where everything is sexually symbolic, perhaps the image that biography has wove of Bram Stoker says as much about the author as it does about our own libidinal culture. Because Stoker is such an elusive biographical subject, it often seems like we are left, like Jonathan at the closing of Dracula, with "hardly one authentic document; nothing but a mass of type-writing" (Stoker 2008: 500). Although it is difficult at times to piece together a life story, it is nevertheless a valid and commendable endeavor. Biographers underline that theirs is an art open to interpretation; a portrait of the artist, rather than an exact reproduction. Paula R. Backscheider drives home this point: "[B]iography is more interesting today because of the acknowledgement that the portrayal of an individual is not the only possible one" (2002: 228). I maintain that the theories surrounding Stoker's libidinal life are well-grounded, and that much has been uncovered on the life of this elusive author. However, the father of the modern vampire remains obscure to this day, with many questions left unanswered. Biographical studies concerned with the life and times of Bram 
Stoker can certainly expect further research on the twinning of this Anglo-Irish writer with the actor Henry Irving, as the two seemed destined to be joined together for all eternity.

\section{Notes}

1 Although Queen Victoria did, in fact, acknowledge same-sex relations between men, she could hardly fathom the notion of erotic love between women, infamously claiming that "No woman would ever do that" when it was brought to her attention (qtd. in Ettorre 1980: 198). Elizabeth Ettorre notes that "Queen Victoria would not believe that it could ever exist. After the passage of the Criminal Law Amendment Bill in 1885 (making homosexual acts between adults punishable by law), Queen Victoria refused to sign the Bill until all references to women were deleted. Lesbianism was unthinkable to the Queen!" (198). In a way, female same-sex love was, for the Victorians, even more abominable than homosexual love between men, since the Queen herself refused to acknowledge its very existence. Same-sex love between women truly was "the love that dare not speak its name."

The connection between the homosocial/homosexual undertones in Dracula and the trial of Oscar Wilde has previously been explored by Talia Schaffer, among others, who underlines that the homosexual inklings in Stoker's famous Gothic tale may be traced back to the author's life-history, and in particular to the individuals in his own authorial circle. In " "A Wilde Desire Took Me': The Homoerotic History of Dracula," Schaffer posits that "Dracula explores Stoker's fear and anxiety as a closeted homosexual man during Oscar Wilde's trial [...] [Dracula's] peculiar tonality of horror derives from Stoker's emotions at this unique moment in gay history" (1994: 381). The "birth" of the homosexual is certainly relevant to the study of the man who was Bram Stoker, yet many critics are left with more questions than answers with regards to the sex life of the author of Dracula. All can unanimously agree, however, that the trial of Oscar Wilde ushered in the idea of the "homosexual" as a label or identity, rather than simply an illegal act. The trial further placed the issue of same-sex love into the spotlight, and soon thereafter homosexuality entered into the "collective consciousness" of Western thought.

Prior to the Victorian era, intimate same-sex relations were largely perceived as abominable acts against oneself and God. In the late eighteenth century, for instance, Immanuel Kant (1724-1804), one of the most prominent and influential philosophers of his age, held that the body became objectified if utilized to satisfy sexual impulses, and specifically addressed the issue of same-sex relations in "Of Crimina Carnis," where he described such deeds as "crimen carnis contra naturam," or "carnal crimes against nature." He outlined that

[Among] the crimina carnis contra naturam is intercourse sexus homogenii, where the object of sexual inclination continues, indeed, to be human, but is changed since the sexual congress is not heterogeneous but homogeneous, i.e., when a woman satisfies her impulse on a woman, or a man on a man. This also runs counter to the ends of humanity, for the end of humanity in regard to this impulse is to preserve the species without forfeiture of the person; but by this practice I by no means preserve the species, which can still be done through a crimen carnis contra naturam, only that there I again forfeit my person, and so degrade myself below the beasts, and dishonour humanity. (2001: 161)

As this excerpt displays, the vilification of same-sex desire was not only, much later, a reality of everyday Victorian life, but was an integral part of Western philosophy for centuries. 
considers "base" instincts to include carnal desires, and he reveals later, in his 1908 essay "The Censorship of Fiction," that texts which contains sexually explicit material should be censored:

There exists a censorship of a kind, but it is crude and coarse and clumsy, and difficult of operation - the police. No one could wish an art so fine as literature, with a spirit as subtle and evanescent as oenanthic ether [...] put under the repressive measures carried out by coarse officials. But it is the coarseness and unscrupulousness of certain writers of fiction which has brought the evil; on their heads be it. (2002: 161)

Stoker further notes that libidinal literature is detrimental to society and, in particular, for Britain's youths, and goes so far as to suggest that such works be outlawed.

In 1878, Stoker left Dublin for London, in order to take the position of manager of the Lyceum Theatre for Henry Irving. Stoker held this post for the next twenty-seven years, and served Irving with extreme loyalty and devotion until the actor's death in 1905 (Dorn 1997). In December 1876, Stoker was invited to Irving's private recital of the ballad The Dream of Eugene Aram by Thomas Hood, and was thereafter devoted to the actor (but only began officially working for him two years later, in 1878) (Belford 1996: 72). Tangentially, these biographers explain that they all have unique "relationships" with their biographical subject. Roth reveals in Bram Stoker that her mission is to bring the figure of Stoker to the fore, claiming that "Stoker remains ignored and unknown despite Dracula" (1982: iii). In Bram Stoker: A Biography of the Author of Dracula, Belford, who claims to feel connected to her subject, reveals that Stoker eventually became her "friend," whom she characterizes as "witty but sad, rigid but responsible, immature but loving" (1996: xv). In Murray's From the Shadow of Dracula: A Life of Bram Stoker, the author pinpoints similarities between Stoker and himself, and states that his alma mater, like Stoker's, is Trinity College, and that his love of horror tales was ignited at a young age, as was Stoker's (2004: xi). What is therefore made clear from the outset is that "identification is no longer seen as a danger [...] in the biographer's relationship with his or her subject" (Peters 1995: 45). Although all of these biographers desire to convey that their lives are tightly intertwined with Stoker's, only Farson has blood ties; Stoker was his great-uncle. This Canadian-born biographer is also the most famous of the Stokerians, as he gained recognition in the 1950s and 1960s as a BBC broadcaster and writer. Farson was also openly homosexual, which he discusses at length in his own 1997 autobiography, Never a Normal Man.

Belford borrows the expression "the shadow of homosexuality" from Elaine Showalter's discussion of Dr. Jekyll and Mr. Hyde in her work Sexual Anarchy: Gender and Culture at the Fin de Siècle, where she elaborates that "the shadow of homosexuality that surrounded Clubland and the nearly hysterical terror of revealing forbidden emotions between men [...] constituted the dark side of patriarchy" (1990: 107). Belford is therefore careful only to suggest - rather than to conclude beyond the shadow of a doubt - that Stoker was a closeted homosexual.

9 Sedgwick further mentions Henry James as the quintessential Victorian bachelor whose sexuality has been the source of much debate. Garnishing considerably more literary attention than Stoker, Henry James's rather mysterious "sexual trajectory" has become an area of interest in both academic and creative writing circles. Leon Edel's watershed biographical work on James left out possible indications of the author's homosexual relations, and caused Edel to experience an "ethical crisis" over the matter. Linda Simon underlines that "[a]lthough Edel allowed for homoeroticism, he refused to consider the possibility of homosexuality, which did not fit the identity of the Henry James whom Edel had created" (2007: 72).

10 Stoker met Wilde at university. Wilde encouraged him to join the university's Philosophical Society while he was its president. Stoker's private thoughts concerning the infamous Wilde trial and the ensuing scandal are ultimately unknown (Belford 1996: 246).

11 The Wilde/Balcombe/Stoker love triangle has been of great scholarly interest to Belford in 
particular. Belford reveals that Balcombe was, in her youth, a famed Victorian beauty and that she left Wilde when Stoker began to pursue her, to the former's great dismay. Wilde wrote to her after their split requesting that she return the gifts he had given her during their courtship (Belford 1996: 85).

Indeed, the Stokerian biographical narratives under study are arguably grounded in a "scenic method of composition," which may be considered narrative "primal scenes." This Freudian concept of childhood trauma, which explains peculiar behaviors later in life, can be employed as a model to uncover the turning points of a biographical subject's life. In Primal Scenes: Literature, Philosophy, Psychoanalysis, Ned Lukacher observes that the concept of the primal scene "should not be constricted to the conventional psychoanalytic understanding of the term" and does not necessarily occur at one particular moment during childhood as Freud contends (1986: 24). Lukacher further underlines that "[t]he primal scene is always the primal scene of words [...] [and that it] is always constructed from what the analystcritic hears or reads in the discourse of the patient-text" (68). As such, the primal scene often involves verbal pronouncements that are considered life-changing for the subject that experiences them.

Thomas Hood's ballad The Dream of Eugene Aram revolves around the story of Aram, who robs and kills an old man for his riches. Stoker witnessed Irving embody the character of the murderous Aram, and at the end of the reading, Stoker was so moved that he reportedly became hysterical (Belford 1996: 74).

Michel Foucault's groundbreaking work A History of Sexuality addresses the perception of hysteria in nineteenth-century Britain. Foucault notes that the Victorians categorized certain individuals into sexually deviant groupings, one of them significantly being "the hysterical woman" (1976: 105).

In the nineteenth century, when a woman went against social conventions, she was often diagnosed as a hysteric. Hysteria was largely perceived to be a female affliction. Showalter further reveals that even women who abided by social norms could be unexpectedly pronounced "mad," thus offering "the second sex" "no protection against [accusations of] hysteria" (1987: 147). In Stokerian fiction, sexual promiscuity in women is often indicative of hysteria.

Conversely, Juliet Mitchell notes in Mad Men and Medusas that "Freud had enthusiastically espoused the propositions of male hysteria following his study visit in 1885 to the Salpêtrière hospital in Paris where Jean Martin Charcot had been demonstrating the hysterical behavior of both male and female patients" (2001: 59). As such, overly sensitive men could, in rare cases, be diagnosed with hysteria.

To be sure, Stoker served Irving so devotedly that he ultimately sacrificed and neglected his own family. Stoker's only child Irving Noel Thornley Stoker - who was naturally named after Irving - openly resented Irving for robbing his father away from him (Belford 1996: 121). As such, it appears that Stoker was more devoted to Irving than he was to his own son, a fact that biographers once again regard as evidence of Stoker's romantic interest in the famous actor.

18 Michael Benton adds that "[s]ome texts will reflect an emphasis upon documentary information about a life, others upon the narrative shape that gives coherence to a life" (2009: 37). In Stoker's case, his biography of Henry Irving, Personal Reminiscences, has served as a primary biographical source, as aforementioned.

19 Stoker's mother, Charlotte Thornley Stoker, is one such individual. As Belford recounts, Charlotte had a significant formative role in shaping her son's literary career. In the first seven years of Stoker's life when he was bed-ridden, his mother entertained him with Irish folk tales as well as true horror stories of her survival of the 1832 cholera epidemic in Sligo, Ireland. Stoker loved her stories so much that he asked her to put them into writing. These stories had a profound impact upon Stoker, and Belford contends that, on some level, he connected the tales of hardship with his own debilitating physical condition (1996: 18). Joseph Valente, author of Dracula's Crypt: Bram Stoker, Irishness, and the Question of Blood, reiterates this point: 
"Stoker's transferential identification with his mother's life-history was probably heightened [...] by the belief that his disabling childhood illness had resulted from contagion following in the potato famine's wake" (2002: 16). Some of these stories included how Charlotte "heard the banshee cry when her mother died; of how some during the famine drank blood from the veins of cattle, including the family cow" (Belford 1996: 18). Belford holds that Stoker's mother "provided the flamboyant genes" and was a source of inspiration for her son long after her story-telling days were over. She was also Stoker's greatest Dracula fan, calling it "splendid" and predicting that "it should make a widespread reputation and much money for you" (Belford 1996: 274). In Dracula, the "good" mother figure has been associated with Charlotte. Belford contends that she informs the character of "the brave and loyal Mina," especially since Dracula is Stoker's most autobiographical work (1996: 5). Biographers therefore make it clear that Stoker's mother "haunts his writing" (Belford 1996: 28).

20 More specifically, Jonathan describes his first encounter with Dracula in his journal entry on May $5^{\text {th }}$.

21 Though I wish to highlight the similarities between the Count and Irving here, it should be noted that Dracula is also depicted as repulsive and animalesque with "peculiarly arched nostrils and hair growing scantily round the temples but profusely elsewhere" (Stoker 2008: 44). Further, the vampire's mouth is "fixed and rather and cruel-looking, with peculiarly sharp white teeth; these protruded over the lips [...] his breath was rank [...] a horrible feeling of nausea came over me [...]" (44-47). Jonathan further observes that "there were hairs in the centre of the palm" (47), a trait commonly associated with masturbation in accordance with nineteenth-century degeneration theory as well as criminal anthropology. It is, thus, important to remember that not all of the passages describing the Count reflect an accurate portrait of the real-life Irving.

More specifically, Jonathan recounts this occurrence in chapter three of his journal.

\section{References}

Adams, James Eli (1999) 'Victorian Sexualities'. In: Tucker, Herbert F. (ed.) A Companion to Victorian Literature \& Culture. Malden, MA: Blackwell. 125-138.

Arata, Stephen (1996) 'Men at Work: From Heroic Friendship to Male Romance'. In: Fictions of Loss in the Victorian Fin de Siècle: Identity and Empire. Ed. Stephen Arata. Cambridge: Cambridge University Press. 79-104.

Backscheider, Paula R. (2002) Reflections on Biography. Oxford: Oxford University Press.

Belford, Barbara (1996) Bram Stoker: A Biography of the Author of Dracula. New York: Alfred A. Knopf.

Benton, Michael (2009) Literary Biography: An Introduction. West Sussex: Blackwell.

Cohen, Jeffrey Jerome (1996) Monster Theory: Reading Culture. Minneapolis: University of Minnesota Press.

Davison, Carol Margaret (ed.) (1997) Bram Stoker's Dracula: Sucking Through the Century, 18971997. Toronto: Dundurn Press.

Dorn, Jennifer (1997) 'The Literary World of Bram Stoker'. British Heritage 18(7). EBSCOhost.

Edel, Leon (1959) Literary Biography. Bloomington: Indiana University Press.

Ettorre, Elizabeth (1980) Lesbians, Women, and Society. New York: Routledge.

Farson, Daniel (1975) The Man Who Wrote Dracula: A Biography of Bram Stoker. London: Michael Joseph.

Farson, Daniel (1997) Never a Normal Man. Toronto: HarperCollins.

Foucault, Michel (1976) The History of Sexuality Vol. 1: The Will to Knowledge. London: Penguin.

Garber, Marjorie (1996) 'Bisexuality and Celebrity'. In: Rhiel, Mary and David Bruce Suchoff (eds.) The Seductions of Biography. New York: Routledge. 13-30.

Hood, Thomas (1831) The Dream of Eugene Aram, The Murderer. London: Charles Tilt. 
Kant, Immanuel (2001) 'Of Crimina Carnis'. In: Heath, Peter and J. B. Schneewind (eds.) Lectures on Ethics. Peter Heath (trans.) The Cambridge Edition of the Works of Immanuel Kant series. Cambridge: Cambridge University Press. 160-62.

Ludlam, Harry (1962) A Biography of Dracula: The Life Story of Bram Stoker. New York: Foulsham.

Lukacher, Ned (1986) Primal Scenes: Literature, Philosophy, Psychoanalysis. Ithaca: Cornell University Press.

Mitchell, Juliet (2001) Mad Men and Medusas: Reclaiming Hysteria. New York: Basic Books.

Murray, Paul (2004) From the Shadow of Dracula: A Life of Bram Stoker. London: Jonathan Cape.

Peters, Catherine (1995) 'Secondary Lives: Biography in Context'. In: Batchelor, John (ed.) The Art of Literary Biography. Oxford: Clarendon Press. 43-56.

Roth, Phyllis A. (1982) Bram Stoker. Boston: Twayne.

Schaffer, Talia (1994) "“A Wilde Desire Took Me": the Homoerotic History of Dracula'. ELH 61(2), 381-425.

Sedgwick, Eve Kosofsky (1985) Between Men: English Literature and Homosexual Desire. New York: Columbia University Press.

Sedgwick, Eve Kosofsky (1990) Epistemology of the Closet. Berkeley: University of California Press.

Senf, Carol A. (ed.) (1993), 'The Drama: Mr. Stoker's Irving' [The Times 5 (1906): 353]. Rpt. in The Critical Response to Bram Stoker. London: Greenwood Press.

Showalter, Elaine (1987) The Female Malady: Women, Madness and English Culture, 1830-1980. London: Virago Press.

Showalter, Elaine (1990) Sexual Anarchy: Gender and Culture at the Fin de Siècle. New York: Viking.

Simon, Linda (2007) The Critical Reception of Henry James: Creating a Master. New York: Camden House.

Smith, Andrew (2004) Victorian Demons: Medicine, Masculinity and the Gothic at the Fin-deSiècle. Manchester: Manchester University Press.

Stoker, Bram (1975) The Annotated Dracula. Ed. Leonard Wolf. New York: Clarkson N. Potter.

Stoker, Bram (2002) 'The Censorship of Fiction'. In: Dalby, Richard (ed.) A Glimpse of America and other Lectures, Interviews and Essays. Essex: Desert Island Books. 154-61.

Stoker, Bram (1999) Letter to William Gladstone, 24 May 1897. Journal of Dracula Studies 1. 48.

Stoker, Bram (2008) The New Annotated Dracula. Ed. Leslie S. Klinger. New York: W. W. Norton.

Stoker, Bram (1906) Personal Reminiscences of Henry Irving. 2 vols. London: William Heinemann.

Valente, Joseph (2002) Dracula's Crypt: Bram Stoker, Irishness, and the Question of Blood. Urbana: University of Illinois Press.

Brigitte Boudreau is a Ph.D. candidate English Studies at the Université de Montréal, where she is examining representations of gender and sexuality in Bram Stoker's life and works. She has published in the Journal of Dracula Studies, Ol3Media, and Romanticism and Victorianism on the Net.

Address: Brigitte Boudreau, Département d'études anglaises, Université de Montréal, C.P. 6128, succursale Centre-ville, Montréal QC H3C 3J7, Canada. [email: brigitte.boudreau.1@umontreal.ca] 
